\title{
Develop an Android-Based Learning Media Integrated with a Scientific Approach to the Colligative Solution's Nature
}

\author{
Yohan Aji Pratama ${ }^{*}$, Zainuddin Muchtar $^{2}$, Ayi Darmana ${ }^{3}$ \\ ${ }_{1,2,3}$ Department of Chemistry Education, Universitas Negeri Medan, Indonesia \\ yohanajipratama@gmail.com
}

\section{Abstract}

This study aimed to develop an Android-based learning media integrated with a scientific approach to the colligative solution's nature. This study uses the Research and Development $(R \& D)$ method with the ADDIE model development stages. The population of the study was all students of class XII SMA using the 2013 curriculum. The

Keywords learning media; android; colligative solution

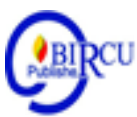
sample was class XII SMA Swasta Al - Azhar Medan. The validation of learning media based on Android integrated scientific approach by material experts and media experts obtained a feasibility score of 4.4 and 4.8 , respectively. In contrast, the feasibility score by two chemistry teachers received an average value of 4.7. The validation of Androidbased learning media integrated with the scientific approach shows that the average score is 4.6, which means that the learning media used has very feasible criteria. Android-based learning media products integrated with the scientific approach were tested on 26 students of class XII at Al-Azhar Medan Private High School. The results showed that the learning media that had been compiled could be used as learning media for the colligative solution's nature.

\section{Introduction}

The advancement of information technology has had a significant influence on all aspects of life, especially in education. The education sector must continually adjust to technological developments to improve education quality (Rusman (2012). The implementation of information technology in the learning process is believed to enhance students' learning abilities. Apart from being used as learning media, information technology can also be used as a learning resource.

The learning process that applies information technology will provide the subject matters that use various media types, which will affect student achievement in a positive way (Ramdhani and Ratna, 2012). Learning using technology media has a significant effect on learning activities. Also, the use of technology in education encourages the emergence of innovations in the learning process so that learning becomes more effective and efficient (Sakat et al., 2012).

Chemistry is a basic science that is abstract and complex. Because of this nature, students do not learn what they learn, such as concepts, problems in the real world, and everyday life (Gilbert, 2008). Learning media are needed to overcome this (Kean and Middlecamp, 1985).

Digital technology has been recognized as a useful teaching tool in research-based learning (Udomrat and Srisawasdi, 2015). Therefore, it has become an important issue to develop methodologies or tools to help students learn in a mobile learning environment. 
Students can learn via mobile devices without being constrained by time and space (Hwang and Chang, 2011). One alternative to developing learning media is mobile learning. Mobile learning influences increasing academic achievement and student interest in the subject matter (Domingo and Gargante, 2016). The presence of mobile learning is intended as a complement to education and provides students opportunities to subject matter that is not mastered anywhere and anytime (Wirawan, 2012).

The development of appropriate media can support the learning process that is integrated into the characteristics of the material and activities that have been defined in the 2013 curriculum. Learning using a scientific approach requires learning media to support the learning process to achieve learning objectives. Learning media can be used as a solution to overcome learning difficulties faced by students.

Mobile learning media is very fast spreading and is one of the most efficient ways to send instruction to higher education in the future (El-Hussein et al., 2010). There is a significant increase between learning motivation and cognitive achievement of students who take learning using Android-based chemistry learning media on buffer solution and hydrolysis material compared to conventional education (Lubis and Ikhsan, 2015).

Also, mobile learning media can improve student learning outcomes and student learning motivation (Jabbour, 2014; Hess, 2014; Calimag et al., 2014; Han and Sin, 2016). Based on the description above, this study aims to develop an Android-based learning media integrated with the scientific approach as a chemical learning media on the nature of colligative solutions for class XII SMA semester 1.

\section{Review of Literatures}

\subsection{Learning Outcomes}

Learning outcomes are measurable achievements that the learner will be able to understand after the learning is complete, which helps learners understand the importance of the information and what they will gain from their engagement with the learning activity.

Creating clear, actionable learning outcomes is an important part of the creation of training programs in organizations. When developing these programs, both management and instructors need to be clear about what learners should understand after completing their learning path. Learning outcomes also play a key role in assessment and evaluation, making clear what knowledge learners should have upon completion of the learning activity. A well-written learning outcome will focus on how the learner will be able to apply their new knowledge in a real-world context, rather than on a learner being able to recite information.

The most useful learning outcomes include a verb that describes an observable action, a description of what the learner will be able to do and under which conditions they will be able to do it, and the performance level they should be able to reach.According to Utomo (2020) education aims to make students happy and make the lives of students better in the future and to achieve happiness in the world and the hereafter based on faith, knowledge, and charity. Resien (2020) stated that Learning is the process of changing behavior due to interactions among individuals and the environment. Changes in behavior include changes in knowledge, understanding, attitudes, skills, motivation, interests, thinking abilities and so on. One of the efforts to improve the quality of education is through improving the teaching and learning process, which contains a series of teacher 
and student actions on the basis of reciprocal relationships that take place in educational situations to achieve certain goals in the learning process. Suparman in Sitorus (2019), argues that "learning is a process of behavior change that can be observed by others including by teachers". Dwidayani in Sitorus (2019) states that, "Learning outcomes are measures of success or failure of students after taking teaching and learning activities both in terms of effective, psychomotor, and cognitive which includes knowledge (memory, understanding, application (application)". Learning outcomes are a form of achievement students as well as a symbol of the success of educators in learning students (Yusuf in Sitorus (2019).

\subsection{Learning Media}

Smaldino in Marpanaji (2014) states that medium (plural, media) is a means of communication used by the sender to convey information to the recipient. The word media comes from Latin which means "between", this term refers to anything that carries information between the source and the recipient[1]. Examples of media include video, television, diagrams, print materials, computer programs, and instructors. Therefore, learning media is a means to convey information from the sender (teacher) to the recipient (student) during the learning activities take place.

In general, learning media is divided into 6 (six) types, namely: (1) Text; (2) Audio; (3) Visual; (4) Motion; (5) Real objects and models; and (6) People[1]. The most commonly used learning media is text-shaped media. This type of text media is used to convey learning material in the form of books, posters, whiteboards, computer screens and others. Other types of media that are often used as learning media are audio, including anything that can be heard, for example, human voice conversations, music sounds, mechanical engine sounds, and others. Visual type learning media are such as diagrams in a poster, images posted on walls (eg wall charts), pictures on a blackboard using chalk or markers, graphics in a learning book, photographs of objects, and others. Motion is a learning media in the form of motion such as videotape, film, and animation. Real objects or models are learning media in the form of three dimensions that can be touched and held by students. An example of a model-shaped learning media commonly used in vocational learning is "trainer"[4]. The last type of media is humans, namely teachers, students, or experts in their fields. Students can learn through teachers, fellow students, or to an expert in their fields.

Thus, various media as mentioned previously will be a medium of learning when they provide messages with instructional goals. The purpose of the media is to facilitate communication and learning. According to Prasasti (2019) Media is a word derived from the Latin medius, which literally means middle, intermediary, or introduction. Learning media is often used interchangeably with the term aids or communication media as stated by Hamalik (in Arsyad, 2013: 4) where he sees that the communication relationship will run smoothly with maximum results when using tools called communication media. The understanding of learning media as above is based on the assumption that the education/learning process is identical to a communication process. In the communication process there are components involved in it, namely the source of messages, messages, and recipients of messages, media, and feedback. The message is the content of the education / teachings contained in the performance of the curriculum as outlined in certain symbols (encoding). The recipient of the message is the student by interpreting these symbols so that they are understood as messages (decoding). The media is an intermediary that channels messages from the source to the recipient of the message. There are several important things that need to be considered in choosing and developing learning media. 
The process of selecting existing media or developing new media is based on context, expectations, conditions of performance, available resources, culture, and practicality [2]. The choice of learning media types is done for several reasons: 1. Learning media is chosen to improve the quality of learning; 2. Learning media is chosen to present and strengthen the most essential knowledge and skills. Media is usually used to present content. The media also functions as a tool to strengthen important points so that learning outcomes can improved; 3. Variations in the use of different types of learning media will strengthen information and offer additional opportunities to strengthen learning without making students repeat the learning material; 4. Learning media is chosen to accommodate differences in student characteristics, especially due to the various learning styles possessed by students. Learning style refers to a group of psychological characteristics that determine how a person feels, interacts in a learning environment.

\subsection{Learning Motivation}

Simanjuntak (2020) argues that Motivation occurs because of a change in energy and drive that exists in a person to achieve a goal with his activities or behavior. Many experts have put forward the notion of motivation with various points of view of their respective experts. From these various opinions have the same core, namely motivation is a driving force that converts the energy in a person into the form of real activities to achieve certain goals. From some of the above meanings, it can be concluded that the notion of motivation is a push that is in someone both from within and from outside a person to do something for the realization of a desired goal. Simanjuntak (2020) argues that Motivation occurs because of a change in energy and drive that exists in a person to achieve a goal with his activities or behavior.

\section{Research Methods}

This research was conducted at Al - Azhar Private High School, Medan. The study was conducted from August 2019 to December 2020. This study included all students of class XII IPA SMA in Medan using the 2013 curriculum. The research sample was taken by purposive sampling.

The study using the Research and Development ( $R \& D$ ) method with the ADDIE model development stages (Analysis, Design, Development, Implementation, and Evaluation). These steps include (1) Analysis (to collect data on existing conditions as a comparison or basic material for the product to be developed), (2) Design (a multimedia design based on the results of the analysis at the analysis stage), (3) ) Development (is the production implementation stage of making products in this study Android-based learning media), (4) Implementation (the use of new learning media that has been developed in real situations in class), (5) Evaluation (measuring the final competence of instructional media).

Assessment of the feasibility of the products Android-based learning media integrated with a scientific approach was carried out by a media expert validator, a material expert validator, and two chemistry teachers. The results of the media development were then tried out and assessed by 26 students of class XII. The data collection technique used in this research is the product feasibility test analysis, where the steps are taken, namely compiling the results of the assessment of media experts, material experts, two chemistry teachers, and 26 students of class XII. 
Table 1. Learning Media Eligibility Criteria

\begin{tabular}{lll}
\hline No & Average & Variable Criteria \\
\hline 1 & $4,2-5,0$ & Very feasible \\
2 & $3,4-4,2$ & $\begin{array}{l}\text { Feasible } \\
\text { Reasonably feasible and does not need } \\
\text { revision }\end{array}$ \\
4 & $1,6-3,4,6$ & $\begin{array}{l}\text { Not feasible for some of the content is } \\
\text { revised } \\
5\end{array}$ \\
& $1,0-1,8$ & Not feasible and needs revision \\
\hline
\end{tabular}

\section{Discussion}

Implementation of the ADDIE model is used to design and develop learning media to create effective and efficient learning activities. Applying the development model is carried out gradually to obtain Android-based learning media integrated with the scientific approach. Before carrying out media development, an initial analysis is carried out, namely literature study, needs analysis, and learning system analysis. This analysis aims to obtain the quality and suitability for the use of the learning media. Development of learning media based on Android integrated scientific approach is carried out using Ms. software. PowerPoint, Ispring Suite 9, and Website 2 APK Builder

\subsection{Results of Learning Media Analysis}

The results of the analysis of learning media based on an android integrated scientific approach using media assessment instruments carried out by material expert validators obtained a feasibility value of 4.4 . from 5 scales (Table 2).

Table 2. Media Assessment by Material Experts

\begin{tabular}{clllcl}
\hline No & \multicolumn{1}{c}{ Aspects } & \multicolumn{1}{c}{$\begin{array}{c}\text { Question Item } \\
\text { Number }\end{array}$} & $\begin{array}{c}\text { Feasibility } \\
\text { Score }\end{array}$ & Criteria \\
\hline 1 & Learning & $1,2,3,4,5$ & 4,4 & Very feasible \\
\hline 2 & Subjects & $6,7,8,9,10,11,12$ & 4,3 & Very feasible \\
\hline 3 & Language & 13,14 & 5,0 & Very feasible \\
\hline \multicolumn{2}{c}{ Average } & $\mathbf{4 , 4}$ & Very feasible \\
\hline
\end{tabular}

Table 3 shows that the media is very feasible. Based on media experts' assessment, all aspects' average value is very feasible with a feasibility score of 4.8 .

Table 3. Media Assessment by Media Expert

\begin{tabular}{cccccc}
\hline No & Aspects & \multicolumn{1}{c}{ Question Item Number } & $\begin{array}{c}\text { Feasibility } \\
\text { Score }\end{array}$ & Criteria \\
\hline 1 & Audio visual & $\begin{array}{l}1,2,3,4,5,6,7,8,9,10, \\
11\end{array}$ & 4,7 & Very feasible \\
\hline
\end{tabular}




\begin{tabular}{llccc}
\hline 2 & $\begin{array}{l}\text { Software } \\
\text { engineering }\end{array}$ & $12,13,14,15,16$ & 4,8 & Very feasible \\
\hline & Average & $\mathbf{4 , 8}$ & Very feasible \\
\hline
\end{tabular}

Table 4 shows that the media that have been developed are following the criteria of media experts. After material experts and media experts tested the media, two chemistry teachers test the media. The results of the assessment of the two chemistry teachers obtained a feasibility score of 4.8 .

Tabel 4. Media Assessment by Teachers

\begin{tabular}{lllcc}
\hline No & \multicolumn{1}{c}{ Aspects } & \multicolumn{1}{c}{$\begin{array}{c}\text { Question Item } \\
\text { Number }\end{array}$} & $\begin{array}{c}\text { Feasibility } \\
\text { Score }\end{array}$ & Criteria \\
\hline 1 & Learning & $1,2,3,4,5$ & 4,7 & Very feasible \\
\hline 2 & Subjects & $6,7,8,9,10,11,12$ & 4,5 & Very feasible \\
\hline 3 & Language & 13,14 & 5,0 & Very feasible \\
\hline 4 & Audiovisual & $\begin{array}{l}15,16,17,18,19, \\
20,21,22,23,24,\end{array}$ & 4,8 & Very feasible \\
\hline 5 & $\begin{array}{l}\text { Software } \\
\text { engineering }\end{array}$ & $25,27,28,29,30$ & 4,8 & Very feasible \\
\hline \multirow{2}{*}{ Average } & $\mathbf{4 , 7}$ & Very feasible \\
\hline
\end{tabular}

The results of the feasibility test conducted by chemistry teachers can conclude that the media is very suitable. After that, the media was tried out on 26 students, and the average score was 4.56 (Table 5).

Table 5. Media Assessment by Students

\begin{tabular}{ccc}
\hline & Feasibility Score & Crite ria \\
\hline Aspects of the subject & 4,53 & Very feasible \\
\hline Aspects of media operational & 4,6 & Very feasible \\
\hline Average & $\mathbf{4 , 5 6}$ & Very feasible \\
\hline
\end{tabular}

From all media feasibility assessments conducted by material experts, media experts, chemistry teachers, and students, the overall average score was 4.6. Thus, Android-based learning media integrated with the scientific approach is very suitable for learning media.

\section{Conclusion}

Based on the development research that has been carried out, android-based learning media is produced. From the assessment results by material experts, media experts, and chemistry teachers and students, Android-based mobile learning media integrated with the scientific approach developed on the subjects of colligative solutions have very suitable criteria for use in learning activities. 


\section{References}

Calimag, J. N., Mugel, P. A., Conde, R. S., \& Aquino, L. B. (2014). Ubquitous learning environment using android mobile application. International Journal of Research in Engineering \& Technology , 2 (2), 119-128.

Domingo, M. G., dan Garganté, A. B. Exploring the use of educational technology in primary education: Teachers' perception of mobile technology learning impacts and applications' use in the classroom. Comput Human Behav 2016; 56: 21-28.

El-Hussein, M.O.M, dan Cronje, J.C. (2010). Defining Mobile Learning in The Higher Education Landscape. Educational Technology \& Society.13

Emda, A. (2011). Pemanfaatan Media Dalam Pembelajaran Biologi di Sekolah. Jurnal Ilmiah DIDAFTIKA, 12 (19), 84-92.

Gilbert, J.K. dan Treagus, D. (2008). Multiple Representations in Chemical Education: Modelsand Modeling in Science Education. Dordrecht : Springer. pp. 251-283.

Han, I., \& Shin, S. W. 2016. The Use of Mobile learning Management System and The Academic Achievement of Online Students. Computers \& Education, Vol. 102, Hal 78-89.

Hwang, Gwo-Jen, dan Chang, Hsun-Fang. (2010). A Formative Assessment-Based Mobile Learning Approach to Improving the Learning Attitudes and Achievements of Students. Journal Elsevire.

Jabbour, K. K. (2014). An Analysis of the effect of mobile learning on lebanse higher education. Informatics in Education, 13 (1), 1-15.

Kean, E. dan Middlecamp, C. (1985). A Survival Manual for General Chemistry (Panduan Belajar Kimia Dasar). Penerjemah: A. Hadyana Pudjaatmaka, Gramedia, Jakarta.

Lubis, I.R., dan Ikhsan, J. (2015). Pengembangan Media Pembelajaran Kimia Berbasis Android untuk Meningkatkan Motivasi Belajar dan Prestasi Kognitif Peserta Didik SMA. Jurnal Inovasi Pendidikan IPA, Volume 1 - Nomor 2, Oktober 2015, (191 201)

Ramdhani, M.A dan Ratna, E.R. (2012). The Analysis of Determinant Factors In Software Design For Computer Assisted Instruction. International Journal Of Scientific \& Technology Research Volume 1, Issue 8

Resien, Sitompul, H., and Situmorang. (2020). The Effect of Blended Learning Strategy and Creative Thinking of Students on the Results of Learning Information and Communication Technology by Controlling Prior Knowledge. Budapest International Research and Critics in Linguistics and Education (BirLE) Journal Vol 3 (2): 879-893.

Rusman. (2013).Belajar dan Pembelajaran Berbasis Komputer. Bandung: Alfabeta.

Sakat, A. A., Mohd Zin, M. Z., Muhamad, R., Ahmad, A., Ahmad, N. A., \& Kamo, M. A. (2012). Educational technology media method in teaching and learning progress. American Journal of Applied Sciences, 9 (6), 874-888.

Sitorus, L.S., Mardianto, and Matsum, H. (2020). Development of Powerpoint-Based Learning Media on Learning Aqeedah Morals. Budapest International Research and Critics in Linguistics and Education (BirLE) Journal Vol 3 (2): 958-964.

Udomrat, Chatsuda., dan Srisawasdi, Niwat. (2015). Evaluation of Secondary School Students' Perception Toward Combination of Digital Learning Technology for Physics Learning. Researchgate.

Utomo, M.R., Hasruddin, and Murad, A. (2020). Influence of Problem Based Learning Models (PBL) and Learning Motivation to Learn Outcomes and Student's Critical 
Thinking Skills Themes of Caring for Life in Class IV Primary School No 026609 Pujidadi Binjai. Budapest International Research and Critics in Linguistics and Education (BirLE) Journal Volume 3 (4): 1634-1643.

Wirawan, et al. (2018). Mobile Learning Based-on Guided Inquiry: optimization of Students' Motivation. Jurnal Pendidikan Teknologi dan Kejuruan, Vol. 24, No. 2, October 2018, 256-261. 